\title{
Assessment of Bagmati river pollution in Kathmandu Valley: Scenario-based modeling and analysis for sustainable urban development
}

\author{
Binaya K. Mishra ${ }^{a}$, Ram K. Regmi ${ }^{\text {b }}$, Yoshifumi Masago ${ }^{a}$, Kensuke Fukushi ${ }^{c}$, Pankaj Kumar ${ }^{a}$, \\ Chitresh Saraswat ${ }^{a, *}$ \\ ${ }^{a}$ United Nations University, Institute for the Advanced Study of Sustainability (UNU-IAS), 5-53-70, Shibuya-Ku, Tokyo 150-8925, Japan \\ ${ }^{\mathrm{b}}$ Environment \& Resource Management Consultant (P) Ltd., P.O. Box: 12419, New Baneshwor, Kathmandu, Nepal \\ ${ }^{\mathrm{C}}$ Integrated Research System for Sustainability Science, University of Tokyo, 7-3-1 Hongo, Bunkyo, Tokyo 113-8654, Japan
}

\section{A R T I C L E I N F O}

\section{Article history:}

Received 28 March 2017

Received in revised form 6 June 2017

Accepted 8 June 2017

Available online $\mathrm{xxxx}$

\section{Keywords:}

River pollution

Wastewater management

Water quality modeling

BOD

$\mathrm{DO}$

\begin{abstract}
A B S T R A C T
Water pollution remains a challenging issue for the sustainable development of Kathmandu Valley despite several infrastructural, awareness-raising and policy measures. The paper assesses the sustainability of the surface water resources of Kathmandu valley by analyzing the water quality parameters such as Dissolved Oxygen (DO) and Biochemical Oxygen Demand (BOD). The case study of Bagmati River pollution is analyzed for current and future wastewater production and treatment scenario based on the two important indicators of aquatic health. The DO and BOD were simulated to assess river pollution along a $25 \mathrm{~km}$ stretch between Sundarijal and Chovar. Water Evaluation And Planning (WEAP) model was used to simulate the current (year 2014) and future (year 2020 and 2030) river water quality conditions. The results showed that the water quality of the Bagmati River is relatively better during monsoon season due to higher river flow in comparison to the dry season. A comparison of simulated DO and BOD values for 2020 and 2030 with 2014 values indicated that the water quality of the Bagmati River within Kathmandu Valley will not significantly improve as a result of the planned wastewater treatment plants requiring additional countermeasures. The study pointed out the inefficiencies of the current practice of discharging untreated sewage into the surface water and causing largely in the river water and unsuitability of river water of water from the Gaurighat to the Chovar area. It is recommended to integrate river water pollution management and maintain ecologically to achieve the healthy urban development.
\end{abstract}

(c) 2017 Published by Elsevier B.V.

\section{Introduction}

In recent years, the volume of wastewater produced in urban areas has increased substantially because of rapid growth in the human population, industrial production, and commercial activities, as well as changes in water consumption behavior. In most urban areas in developing nations, excess wastewater is disposed of directly, or without effective treatment, into surface water bodies, resulting in their severe degradation; despite the adoption of countermeasures (Ismail and Abed, 2013; Purandara et al., 2011). Water pollution threatens the sustainability of urban systems. Pollution in the Bagmati River

\footnotetext{
* Corresponding author.

E-mail address: saraswat.chitresh@gmail.com (C. Saraswat).
} 
is a serious concern for the sustainable development of the Kathmandu Valley (Shrestha et al., 2015; Regmi et al., 2014; ICIMOD, 2007). The quantity and quality of river water, particularly during the dry season, is at very alarming levels along most of the river's course through the valley. The water quality problems affecting the Bagmati River include low dissolved oxygen concentrations, bacterial contamination, and metal toxicity. The uncoordinated rapid urban expansion, inadequate wastewater treatment facilities, low levels of awareness, lack of regulations and insufficient adherence to municipal and industrial wastewater generation laws are considered to be the primary reasons for pollution in the Bagmati River. Some sewer lines connect directly to the Bagmati River and its tributaries. Only a few kilometers of uppermost section (high mountain with a catchment area of $17 \mathrm{~km}^{2}$ ) is only suitable for drinking water supply. Remaining sections are not used for potable purposes due to greater water quality deterioration. Wastewater management in the valley is limited to the collection of wastewater from different sources through open and underground sewer lines and disposal of untreated wastewater into the rivers (Regmi et al., 2013). Although a number of wastewater treatment plants have been constructed in Kathmandu Valley only one the Guheshwori wastewater treatment plant is currently functional (Table 1). The proposed Kathmandu Valley Wastewater Management Project (KVWMP) of the Government of Nepal is aimed at improving wastewater services in Kathmandu Valley through extensive investment in rehabilitation and expansion of the sewerage network, as well as modernisation and construction of new wastewater treatment plants (ADB, 2013). Construction/rehabilitation of WWTP is expected to help for other uses like irrigation (downstream of Kathmandu valley), recreation etc.

Previous research has been limited to the assessment of current water quality conditions using observation or simulated data. Planning and management activities require the assessment of both current water quality conditions and also future possible scenarios. Assessment of the current situation and future outlook for Bagmati River pollution is intended to explore alternative wastewater management options. The formulation of water quality management strategies requires interdisciplinary analysis of various potential causes of water quality degradation as well as corresponding solutions (Kannel et al., 2007; McIntyre and Wheater, 2004). Mathematical models simulate the pollution of water bodies for likely wastewater production and treatment scenarios (Deksissa et al., 2004; Cox, 2003; Radwan et al., 2003). Computer-based mathematical models can predict water quality. These models may be based on physical data, or a simplified conceptual or empirical approach. Selection of a water quality model depends on data availability, calculation time and intended output variables. Although several models, including QUAL2K and MIKE11, provide detailed insight into water quality conditions in a river system, there are very few models that consider policy-setting issues in detail. The Water Evaluation and Planning (WEAP) model, a decision support system of the Stockholm Environmental Institute, is widely used for integrated water resource planning and management (Sieber and Purkey, 2011). Although the WEAP water quality module does not provide the same level of detail on water quality variables as several other models, it supports scenario formation functionalities, where policy alternatives can be taken into account for current and future conditions. The WEAP hydrology module allows for estimation of rainfall-runoff and pollutant travel from a catchment to water bodies (Ingol-Blanco and McKinney, 2013). Using WEAP model, various scenarios are developed based on variables such as population growth, industrial and commercial activities, land use, the status of treatment plants and sewerage network, and several other factors that can significantly impact wastewater levels. WEAP provides a GIS-based interface to represent graphically wastewater generation and treatment systems. A variety of applications of WEAP for water quality modeling and ecosystem preservation have been reported (Slaughter et al., 2014; Assaf and Saadeh, 2008). Also, WEAP can simulate several conservative water quality variables (which follow exponential decay) as well as non-conservative water quality variables, in addition to pollution generation and removal at different sites which is one of the important reason to use WEAP model in the study. The model with its built-in functions can estimate Dissolved Oxygen (DO), Biochemical Oxygen Demand (BOD) and water temperature; and can be also linked to QUAL2K to simulate far more detailed water quality variables, including nitrogen, phosphorous, sedimentation, algae, $\mathrm{pH}$, and pathogen levels. Comparing simulated water quality values with acceptable (standard) values is helpful for determining if a point or non-non-point source is releasing excessive pollutant. DO and BOD are two widelyused indicators for river pollution (Radwan et al., 2003; Bhutiani and Khanna, 2007; Ingol-Blanco and McKinney, 2013). The volume of confined oxygen in water is characterized by DO values, and excessive disposal of untreated wastewater results in a decrease in DO levels. Although aquatic animals (e.g. fish) can survive at low DO levels ( $<5 \mathrm{mg} / \mathrm{l})$, prolonged exposure will diminish their normal growth patterns. Usually, water bodies with $\mathrm{DO}<2 \mathrm{mg} / \mathrm{l}$ are considered extremely polluted and result in the die-off of most aquatic animals (Gower, 1980). The BOD is another important pollution indicator and increases along with higher waste concentrations. It is a measure of the dissolved oxygen necessary for microorganisms

Table 1

Existing and planned wastewater treatment plants in Kathmandu Valley.

\begin{tabular}{|c|c|c|c|c|c|c|}
\hline \multirow[t]{2}{*}{ Wastewater treatment plant } & \multicolumn{3}{|c|}{ Design capacity, MLD (Million Litre per Day) } & \multicolumn{3}{|c|}{ Design effluent standard (BOD mg/l) } \\
\hline & 2014 & 2020 & 2030 & 2014 & 2020 & 2030 \\
\hline Guheshwori & 16.4 (partially working & 30.6 & 30.6 & 25 & 15 & 15 \\
\hline Gokarna & - & 0.6 & 0.6 & - & 15 & 15 \\
\hline Sallaghari & 2 (virtually not working) & 13.1 & 13.1 & - & 50 & 30 \\
\hline Kodku & 1.1 (virtually not working) & 7.0 & 11.2 & - & 50 & 30 \\
\hline Dhobighat & 15.4 (not working) & 39.2 & 81.6 & - & 50 & 50 \\
\hline
\end{tabular}


to decompose waste substances. River sections with BOD values of more than $15 \mathrm{mg} / \mathrm{l}$ are considered to be severely polluted (Lai et al., 2013).

This research simulated DO and BOD along sections of the Bagmati River in Kathmandu Valley to identify water environment degradation problems and explore wastewater pollution management options. Examination of DO and BOD values can help to determine acceptable maximum pollution loads. This research reviewed different kinds of literature on the Bagmati River Basin to understand its physiography, hydroclimatology, wastewater generation and management systems. The WEAP permitted all this to be done, including scenario modeling by interfacing with different elements that significantly affect wastewater generation and treatment. The DO and BOD values were simulated under one of the most likely scenarios by 2020 and 2030 to analyze current conditions and the future outlook of the urban water environment. Finally, simulated current and future DO and BOD values were compared in order to explore alternative wastewater management options for enhancing the urban water environment of the Kathmandu Valley towards a sustainable urban water system.

\section{Study area and data}

This study focuses on a $25 \mathrm{~km}$ length of the Bagmati River inside Kathmandu Valley ranging between Sundarijal and Chovar sections ( $27^{\circ} 32^{\prime} 13^{\prime \prime}-27^{\circ} 49^{\prime} 10^{\prime \prime}$ north and $85^{\circ} 11^{\prime} 31^{\prime \prime}-85^{\circ} 31^{\prime} 38^{\prime \prime}$ east). The Bagmati catchment drains an area of $595.4 \mathrm{~km}^{2}$ with Chovar as its outlet (Fig. 1). The altitude of the basin area varies from 1178 to $2723 \mathrm{~m}$ above mean sea level. The Bagmati River is an important source of water for drinking, industrial, irrigation, recreational, cultural and religious uses. According to the 2011 census of Nepal, more than 2.3 million people live in the study area.

Water quality modeling requires various input data including point and non-point pollution sources, quantities, locations, concentrations, wastewater treatment plants, water temperatures, climate, drainage network, river flow-stage-width relationships, river length, water quality at head flows, groundwater and surface water inflows. The flow of wastewater into the Bagmati River and its tributaries mainly feeds through domestic, industrial and stormwater runoff routes. Kathmandu Upatyaka Khanepani Limited (KUKL) is responsible for operating and managing the water supply and wastewater services in the Kathmandu Valley through a public-private partnership (Shukla et al., 2012; ADB, 2013). There are no precise data available on the total volume of wastewater produced from different sources. In the absence of detailed information, the daily volume of domestic wastewater generated is based on an estimated 75 liters of average daily consumption per capita (UNEP, 2001). Comparing the volume of domestic and industrial wastewater in the five municipalities of Kathmandu Valley, it is estimated that industrial wastewater contributes about $7 \%$ of the domestic wastewater generated in each of the municipalities. Governmental and non-governmental agencies have launched various water pollution management initiatives, including the construction of several wastewater treatment facilities and supporting sewage networks (ADB, 2013; GoN, 2009). A number of wastewater treatment plants were constructed over the year by the government of Nepal. However, except one with less than half of its capacity working, most of the plants stopped working completely mainly due to the inadequate budget allocation for maintenance and running cost and power shortage. Table 1 provides information on existing and proposed wastewater treatment plants, which were used for the scenario analyses. KVWMP aims to improve the

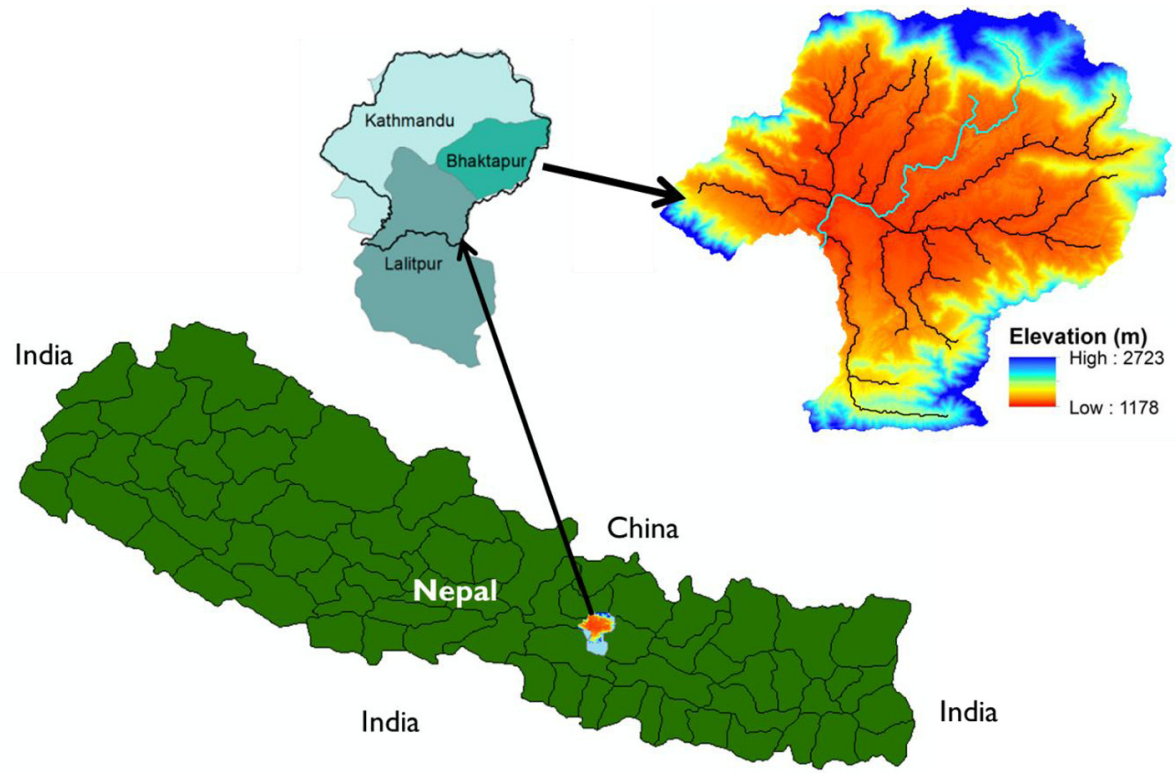

Fig. 1. Location of the Bagmati River Basin. 
wastewater management system by maximizing the efficiency and effectiveness of existing wastewater sector infrastructures and construction of new of wastewater management facilities in Kathmandu Valley. Existing wastewater treatment facilities at Gokarna, Guheshwori, Sallaghari, Kodku and Dhobighat will be rehabilitated and upgraded and their treatment capacity will be increased. A new wastewater treatment facility will be constructed in Khokana. This is not mentioned in the table as it is located few kilometers outside (downstream) of the study area. Rehabilitation and construction of the wastewater management systems are proposed in terms of two timelines (2020 and 2030).

Wastewater and stormwater flow paths to the Bagmati River were considered largely as natural drainage networks owing to the lack of reliable data on sewerage and drainage systems. The Digital Elevation Model (DEM) data is used to derive hydrological features. A freely downloadable ASTER (Advanced Spaceborne Thermal Emission and Reflection Radiometer) DEM with the 30-meter spatial resolution was used to delineate drainage networks for analysis. The entire study area was divided into 14 sub-basins with consideration for the influent locations of major tributaries. Fig. 2 shows sub-basins and locations of streamflow and water quality monitoring stations within the Kathmandu Valley.

Land use information was derived using a 30-meter resolution Landsat image from 7 November 2009. The study area was analyzed in three categories: agricultural (44\%), forest (36\%) and built-up areas (19\%). Soil data parameters were identified using previous literature and a comparison of rainfall, observational and simulated runoff (Amato, 2006; Yates et al., 2005). The different hydro-climatic data are required to estimate stormwater runoff and water quality model. Climate data consist of monthly rainfall, air temperature, relative humidity and wind velocity, and have been collected at the Kathmandu airport station from 1968 to 2014 by the government's Department of Hydrology and Meteorology.

The mean annual rainfall is $1454 \mathrm{~mm}$, with about $80 \%$ of rain falling from June to September. Rainfall varies considerably during the year with monthly averages ranging from $7 \mathrm{~mm}$ (November) to $370 \mathrm{~mm}$ (July). Monthly average temperatures during the year were found to vary from $10.4{ }^{\circ} \mathrm{C}$ (January) to $24.2{ }^{\circ} \mathrm{C}$ (August). The annual average relative humidity and wind speed were found to be $75 \%$ and $1 \mathrm{~m} / \mathrm{s}$. Historical mean monthly streamflow from 2000 to 2014 at the Chovar section was used to calibrate and validate the WEAP hydrology module simulation. Several commonly used water quality parameters available from different governmental and non-governmental agencies were collected; measurements were also recorded at various locations along the river. Water quality data (DO, BOD, water temperature) from 2000 to 2014 along different sections of the Bagmati River were used for the water quality modeling.. Table 2 provides descriptions of water sample collection and analysis for different physicochemical parameters.

\section{Methods}

A WEAP model was used to simulate rainfall-runoff and water quality variables as well as to set up scenarios for assessing water quality management and policy alternatives in the Bagmati River Basin. Spatio-temporal river pollution analyses were carried out with consideration of the increasing trend in wastewater generation and proposed new and rehabilitated wastewater treatment plants (WWTP). The analyses had three major components: hydrologic, water quality and scenario modeling.

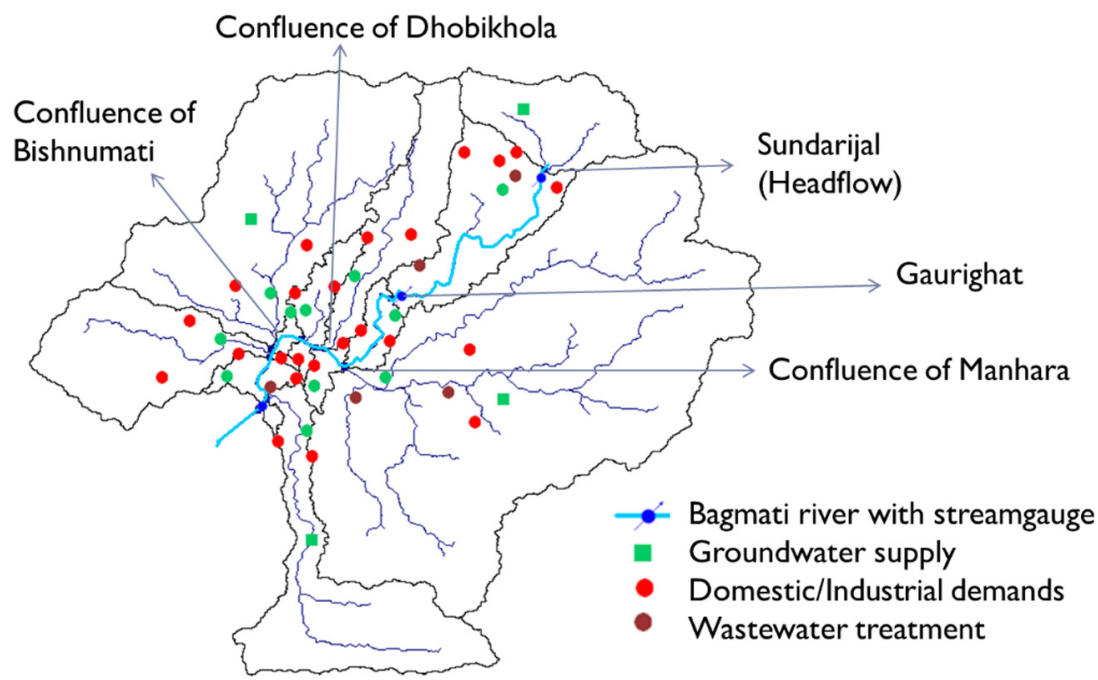

Fig. 2. Bagmati River network and locations of wastewater treatment plants, water quality stations, and streamflow-measurement stations in Kathmandu Valley. 
Table 2

Summary of physicochemical data of water samples.

\begin{tabular}{|c|c|c|c|c|c|c|c|c|}
\hline \multirow[t]{2}{*}{ Parameters } & \multirow[t]{2}{*}{ Test Method } & \multirow{2}{*}{$\begin{array}{l}\text { Sampling } \\
\text { location }\end{array}$} & \multicolumn{3}{|c|}{$\underline{\text { Primary Data }}$} & \multicolumn{3}{|c|}{$\underline{\text { Secondary Data }}$} \\
\hline & & & Year & No. of obsrv & Source & Year & No. of obsrv & Source \\
\hline $\mathrm{DO}(\mathrm{mg} / \mathrm{l})$ & $\begin{array}{l}\text { Electrometric HANA Probe (Precision level of } \\
1 \% \text { ) }\end{array}$ & 5 & 2014 & time/year & Self & $\begin{array}{l}2000- \\
13\end{array}$ & $\begin{array}{l}\text { 1-2time/ } \\
\text { year }\end{array}$ & DHM \\
\hline BOD (mg/l) & Winkler Azide method (Error < 5\%) & 5 & 2014 & $\begin{array}{l}4 \text { times/ } \\
\text { year }\end{array}$ & Self & $\begin{array}{l}2000- \\
13\end{array}$ & $\begin{array}{l}1 \text {-2time/ } \\
\text { year }\end{array}$ & DHM \\
\hline
\end{tabular}

(Source: Self).

(Obsrv- Observation, DHM - Department of hydrology and meteorology).

\subsection{Hydrologic modeling}

Hydrologic modeling requires the entire study area to be split into smaller catchments with consideration of confluence points, physiographic and climatic characteristics. WEAP's hydrology module can model catchment runoff and pollutant transport processes into a river. Among the different estimation methods under the hydrology module, the most sensitive is the soil moisture method. This method can simulate different components of the hydrologic cycle, including evapotranspiration (ET), surface runoff, interflow, base flow, and deep percolation (Sieber and Purkey, 2011). Empirical equations are employed to describe the rainfall-runoff and pollutant transport processes. With the soil moisture method, each catchment is split into two soil layers: upper and lower, representing shallow water and deep water capacities, respectively. The upper soil layer accounts for spatial variation in different kinds of land use and soil types. The lower soil layer represents groundwater recharge and baseflow processes, and its parameters remain the same for the entire catchment. Different hydrological components are estimated with z1 and z2 as initial relative storage (\%) for upper (root zone) and lower (deep) water capacity, respectively (Eqs. (1)-(5)).

Pollutant transport from a catchment accompanied by rainfall-runoff is enabled by ticking the water quality modeling option. Pollutants that accumulate on catchment surfaces during non-rainy days reach water bodies through surface runoff. The WEAP hydrology module computes catchment surface pollutants generated over time by multiplying runoff volume and concentration or intensity of different types of land use.

$$
\begin{aligned}
& E T=\text { Potentialevapotranspiration } \times\left(5 z_{1}-2 z_{2}^{2}\right) / 3 \\
& \text { Surface runoff }=\text { Precipitation }(P) \times z_{1}^{\text {Runoff resistance factor }} \\
& \text { Interflow }=(\text { Root zone conductivity } \times \text { preferred flow direction }) \times z_{1}^{2} \\
& \text { Percolation }=\text { Root zone conductivity } \times(1-\text { preferred flow direction }) \times z_{1}^{2} \\
& \text { Baseflow }=\text { Deep conductivity } \times z_{2}^{2}
\end{aligned}
$$

\subsection{Stream water quality modeling}

The water quality module of WEAP makes it possible to estimate pollution concentrations in water bodies and is based on the Streeter-Phelps model. In this model, the simulation of oxygen balance in a river is governed by two processes: consumption by decaying organic matter and reaeration induced by oxygen deficit (Sieber and Purkey, 2011). The BOD removal from water is a function of water temperature, settling velocity, and water depth (Eqs. (6)-(9)):

$$
\begin{aligned}
& B O D_{\text {final }}=B O D_{\text {init }} \exp ^{\frac{-k_{r B O D} L}{U}} \\
& \text { where } k_{r B O D}=k_{d 20}^{1.047(t-20)}+\frac{v_{s}}{H}
\end{aligned}
$$

$B O D_{\text {init }}=$ BOD concentration at beginning of reach $(\mathrm{mg} / \mathrm{l})$

$B O D_{\text {final }}=$ BOD concentration at end of reach $(\mathrm{mg} / \mathrm{l})$

$t=$ water temperature (in degrees Celsius)

$H=$ water depth $(\mathrm{m})$

$L=$ reach length $(\mathrm{m})$

$U=$ water velocity in the reach

$v_{s}=$ settling velocity $(\mathrm{m} / \mathrm{s})$

$k_{r}, k_{d}$ and $k_{a}=$ total removal, decomposition and aeration rate constants ( $1 /$ time)

$k_{d 20}=$ decomposition rate at reference temperature $\left(20^{\circ}\right.$ Celsius $)$ 
The oxygen concentration in the water is a function of water temperature and BOD:

$$
\begin{aligned}
& \text { Oxygen saturation or } O S=14.54-(0.39 t)+\left(0.01 t^{2}\right) \\
& O_{\text {final }}=O S-\left(\frac{k_{d}}{k_{a}-k_{r}}\right)\left(\exp ^{-k_{r} L / U}-\exp ^{-k_{a} L / U}\right) B O D_{\text {init }}-\left[\left(O S-O_{\text {initial }}\right) \exp ^{-k_{a} L / U}\right]
\end{aligned}
$$

$O f_{\text {inal }}=$ oxygen concentration at end of reach $(\mathrm{mg} / \mathrm{l})$

$O_{\text {initial }}=$ oxygen concentration at beginning of reach $(\mathrm{mg} / \mathrm{l})$

Ideally, field measurements should be carried and analyzed to obtain values for the different parameters. Owing to lack of time and funds, most water quality parameters have been estimated from other reported work (Bowie et al., 1985).

\subsection{Model setup}

To model water quality with WEAP, it is necessary to have a virtual representation of the contributory elements of the water pollution in the study area. Vector or raster layers of drainage networks are added to identify river reaches and confluence points. A river is represented by a line with an arrow at the end to show upstream to downstream gravity water flow. Information on water quantity/quality and flow-stage-width is required at the head (upstream) section. At a confluence point, river discharge represents the sum of all upstream flows. Demand sites in the WEAP model represent services where water is used and returned to water bodies (rivers, lakes, coasts etc.) with degraded quality.

In the current study, demand sites are meant to identify domestic (population) and industrial centers. Demand sites are described via their attributes describing consumption and wastewater pollution loads per capita, water supply source, and wastewater return flow. Dynamic attributes are described as functions of time and include population and industries. Catchment and runoff links are provided to estimate stormwater flow and pollution generation from different types of land use (agricultural, forest and built-up areas). WWTP are pollution handling facilities with design specifications including total capacity and removal rates of pollutants.

Assessment of future river water quality conditions is carried out by defining a time horizon for which alternative wastewater generation and management options are explored. The business as the usual condition is represented by a reference scenario with a selection of all the existing elements as currently active. Alternative wastewater management options can be introduced by proposing changes vis-à-vis the reference scenario. These changes may include activating, deactivating or modifying attributes of elements or parameters. Consequently, the new/improved WWTPs can be modeled as scenarios representing deviations from the current conditions (reference scenario). The timeframe for future modeling and analysis of Bagmati river pollution have been largely based on the master plan of the KUKL which is responsible for managing water supply and sanitation in the Kathmandu valley. KVWMP of KUKL with funding from ADB is considered a major step in addressing the problem of river water pollution inside the Kathmandu valley. Rehabilitation and construction plan of wastewater water management systems under this project is outlined in terms of 2020 and 2030 timeframe.

In all, 24 demand sites, one for each of the sub-catchments, were placed at the WEAP platform to represent wastewater generation centers. These sites include domestic and industrial centers. Five WWTPs, the partial operational Sundarijal facility and the remaining new/improved facilities for future scenarios are located at Gokarna, Sallaghari, Kodku and Dhobighat. Using the WEAP interface, the schematic overview of the study area was designed, which showed the water quality's different components and association in the Kathmandu Valley. Information on each object can easily be retrieved by clicking the corresponding graphical element. Under current reference scenario (the baseline year 2014), only the Sundarijal WWTP was partially operational (reduced treatment capacity). To model future conditions, all five proposed new/improved WWTPs were enabled by defining respective start-up years.

\section{Results and discussion}

\subsection{Model performance evaluation}

Prior to conducting scenario analyses, it is important to evaluate the simulation performance of the hydrology and water quality modules in the WEAP tool. Performance evaluation was based on the visual match and percentage error between observed and simulated monthly or seasonal values. The model performance was evaluated for the period from 2001 to 2014. The model parameters were adjusted manually via trial and error method. The adjustments in model parameters were directed towards achieving smaller absolute mean error, widely-used statistical criteria for assessing any model performance. Additionally, Nash-Sutcliffe efficiency (NSE) (Nash and Sutcliffe, 1970) value was checked for hydrologic module performance because of its widespread use in hydrological modeling (Eq. (10)). 


$$
N S E=1-\frac{\sum_{I=1}^{n}(S i-O i)^{2}}{\sum_{I=1}^{n}(O i-\bar{O})^{2}}
$$

where $S_{i}$ is the simulated value at time $i, \bar{S}$. the mean simulated value, $O_{i}$ is the observed value at time $i, \bar{O}$. the average of the observed values and $n$ is the number of data points. The NSE value ranges from 0 to 1 . According to Moriasi et al., 2007, the performance of the model is acceptable when the NSE and $\mathrm{R}^{2}$ values are both greater than 0.5 .

Hydrology module parameters were adjusted in order to reproduce the observed monthly stream flows. Adjustments to hydrology module parameters were made with consideration for both quantitative and qualitative evaluations of the hydrologic response at the Chovar stream gauge section. Effective rainfall and runoff/infiltration parameters were adjusted while trying to match the values of simulated and observed discharge series. NSE value of 0.94 for Chovar station shows that the results of the model calculations achieved enough credibility. Fig. 3 compares monthly simulated and observed streamflows at Chovar, showing that they largely match for most months, with an error of $2-19 \%$.

After adjusting the parameters and evaluating the performance of the hydrologic module, the forecasting of water quality trend based on the projected scenario of wastewater discharge and treatment were conducted. The simulation performance of the water quality module was evaluated by comparing DO and BOD at the Gaurighat and Minbhavan sections of the Bagmati River. Selection of these two sections was made on the basis of availability of longer observational water quality data. Figs. 4 and 5 compare simulated and observed DO and BOD at the Gaurighat and Minbhavan locations. Additionally, trends in simulated and observed DO and BOD were checked at several other locations along the Bagmati River. Again, the percentage error at these locations was found to be smaller than $20 \%$. In general, these results indicate that the hydrology and water quality modules of the WEAP tool effectively reproduce the hydrological and water quality dynamics of the basin.

\subsection{Assessment of river water quality conditions}

For the assessment of the future water quality condition the policy analysis is performed, which treats major driving factors as the control variables to form different simulation schemes. A scenario-based planning approach helps to answer what-if queries by predicting and analyzing future water pollution outlooks. Scenarios are proposed to consider current conditions (business-as-usual) and future outlook (potential intervention) to address water pollution problems. In this study, the WEAP model was used to formulate scenarios that represent current conditions and future countermeasures by KUKL.

The spatio-temporal impact of maintaining the status quo versus implementing the plans on the Bagmati River was assessed. With 2014 as the baseline year, BOD and DO were simulated and compared for 2020 and 2030 with wastewater generation and new/rehabilitated WWTPs scenarios. A sample of DO and BOD levels generated by the WEAP model is presented to describe the pollution of surface water in the Bagmati River with respect to flow variability, spatial extent, future trends and alternative water quality management options. For $\mathrm{DO}<2$ and $\mathrm{BOD}>15$, a river section can be considered severely polluted (Lai et al., 2013). The Figs. 6 and 7 show fluctuations in DO and BOD along the Bagmati River in January 2014. A general analysis of the longitudinal profiles of the quality parameters simulated for the monsoon and dry months reveals significant variation in their DO and BOD values. A Large portion of the Bagmati River was found to be critically polluted. DO decreases and BOD increases as the river flow towards the center of the city. In most parts of the river, DO is less than $5 \mathrm{mg} / \mathrm{l}$ and BOD is more than $15 \mathrm{mg} / \mathrm{l}$. This indicates that the quality of river water is extremely poor and not suitable for aquatic life or agricultural use.

River water quality is largely influenced by streamflow conditions. Higher levels of river discharge promote natural cleansing and dilute river pollution. Therefore, a pollutant which has hardly any impact on river water quality during periods of high runoff can significantly degrade water quality during dry and warm periods. This phenomenon can be highly impor-

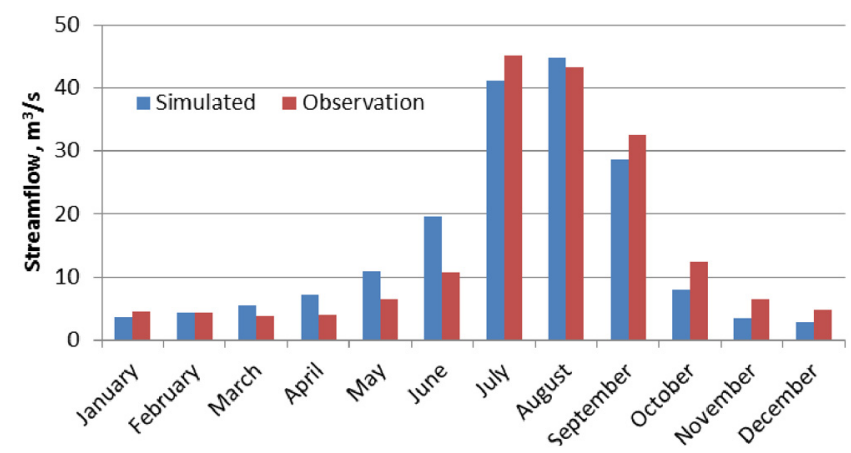

Fig. 3. Comparison of simulated and observed monthly discharge at Chovar. 


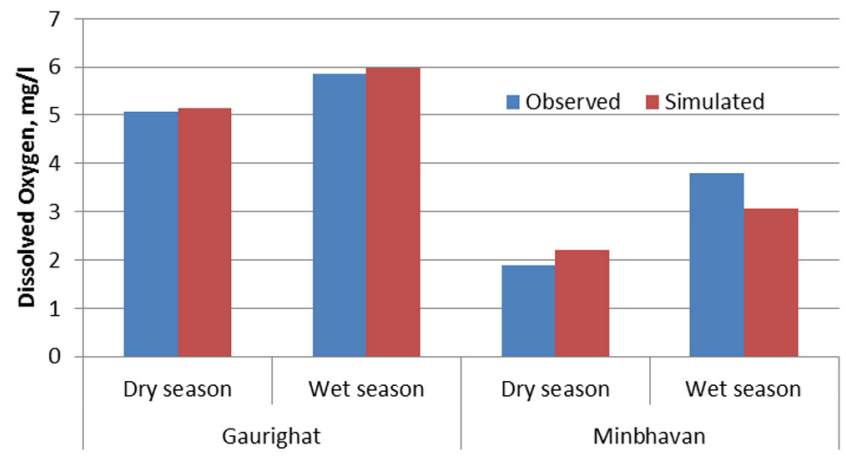

Fig. 4. Comparison of simulated and observed DO during dry and wet seasons.

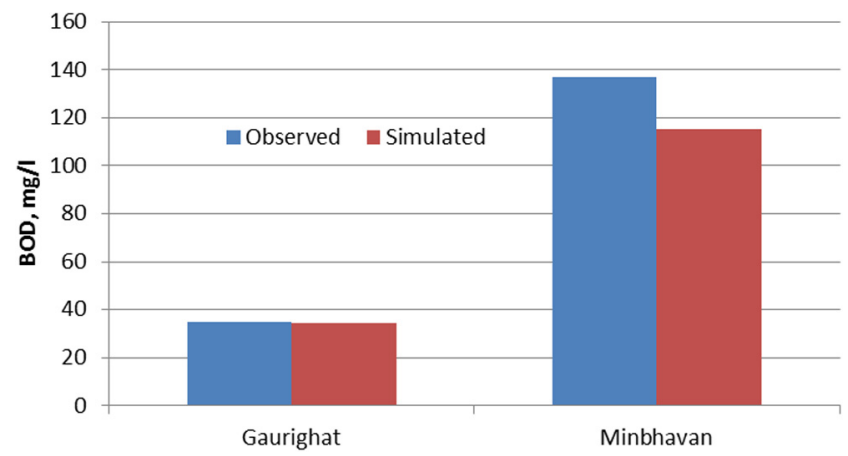

Fig. 5. Comparison of simulated and observed BOD during dry season.

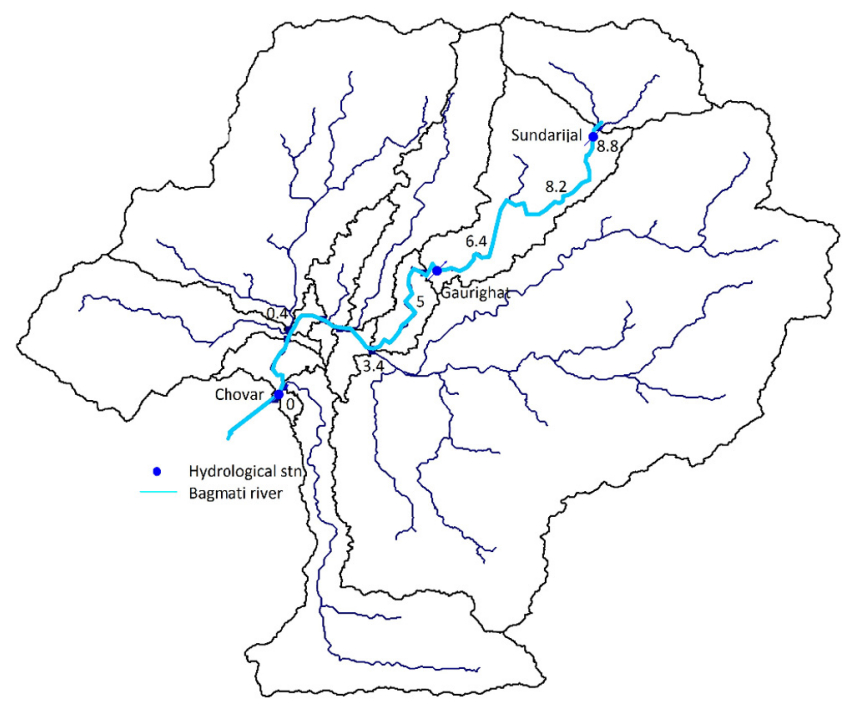

Fig. 6. DO variation ( 8.8 to $0 \mathrm{mg} / \mathrm{l}$ ) along the Bagmati River in January 2014 .

tant for the Bagmati River, because of larger river discharge fluctuations during the monsoon (June-September) and dry months. Table 3 showed the comparative plots of monthly DO and BOD values at five locations on the Bagmati River from upstream to downstream areas. In general, there are consistent seasonal variations in DO and BOD levels strongly associated with river discharge as DO and BOD approach $0 \mathrm{mg} / \mathrm{l}$ and $200 \mathrm{mg} / \mathrm{l}$ during the dry months of the year. The higher concentrations of DO and BOD in the dry months are also associated with the lower capacity for natural self-purification and dilution of pollutants due to reduced flows. Although it was believed that the river water pollution will be largely sorted out after 


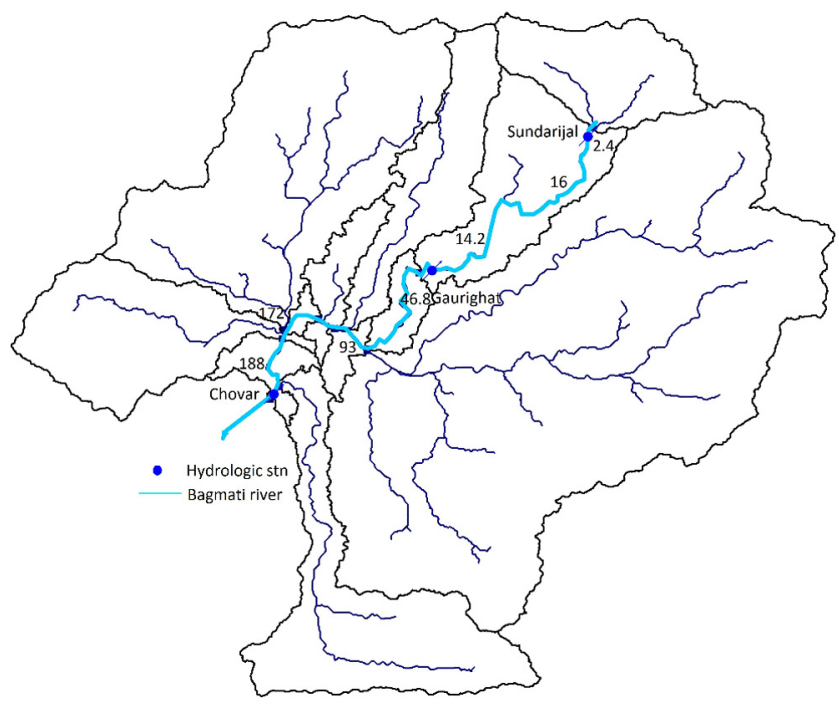

Fig. 7. BOD variation (2.4 to $190 \mathrm{mg} / \mathrm{l}$ ) along the Bagmati River in January 2014.

Table 3

Comparative Analysis and Projection of BOD and DO at different locations in Kathmandu Valley along the Bagmati River in 2014,2020 and 2030.

\begin{tabular}{|c|c|c|c|c|c|c|}
\hline \multirow[t]{2}{*}{ Location } & \multicolumn{3}{|c|}{$\mathrm{BOD}(\mathrm{mg} / \mathrm{L})$} & \multicolumn{3}{|c|}{$\mathrm{DO}(\mathrm{mg} / \mathrm{L})$} \\
\hline & 2014 & 2020 & 2030 & 2014 & 2020 & 2030 \\
\hline Gokarna & 15.07 & 16.72 & 20.10 & 6.01 & 6.01 & 5.85 \\
\hline Gaurighat & 33.06 & 39.29 & 42.32 & 5.38 & 5.19 & 4.72 \\
\hline Minbhavan & 86.46 & 97.05 & 109.03 & 2.49 & 2.36 & 2.18 \\
\hline Teku & 117.61 & 131.4 & 148.04 & 1.31 & 1.17 & 1.05 \\
\hline Dhobighat & 118.0 & 131.98 & 148.93 & 1.013 & 0.92 & 0.82 \\
\hline
\end{tabular}

the establishment of the new/rehabilitated WWTPs, plots of 2020 and 2030 show that DO and BOD values will remain far beyond acceptable limits. These data demonstrate that the current, as well as new/rehabilitated wastewater treatment plants, are largely inadequate to alleviate the Bagmati river pollution. By 2030, river water pollution will be much worse. There will be an increase of wastewater generation due to the greater population and socio-economic development despite rehabilitation, up-gradation and new wastewater management systems.

Therefore, the new/rehabilitated wastewater infrastructures need to be expanded further with the increase of population, lifestyle and other socio-economic development activities resulting in a significant increase of wastewater. The quantity of wastewater generation is closely connected with management or pattern of water consumption. Thus, the simulation results of the WEAP model with adaptation scenarios can contribute to the improvement of water consumption pattern. One of the alternative measures for reducing water consumption and wastewater generation could be changes in the water utility pricing system. Alternative pricing such as an increase in water utility service fee (sum of water supply and sanitary service charges) can help in optimal use (reduction) of water consumption and also increase revenue for sustainable operation and management of water infrastructures.

Water quality simulation in this study was based on the mean behavior of the system. However, the wastewater generation rate, as well as water quality parameters, may be significantly different depending on the location, community, catchment, daily variation in streamflow in the rainy season and various others. Obviously, in 2020 and 2030 , if there are no drastic measures to control pollution sources, Bagmati River water quality will be no longer eligible to supply for any practical purposes. Therefore, to ensure the water quality in future eligible for different uses, it is required now to have timely solutions to solve this problem.

\section{Conclusions and recommendations}

\subsection{Conclusions}

This study assessed current and future water pollution conditions of the Bagmati River within the densely populated Kathmandu Valley in order to explore alternative river pollution management options. The extent of pollution caused by releasing untreated sewage into the river system and the impact of the different wastewater treatment plants were deter- 
mined. Hydrology and water quality modules of the WEAP tool were employed to simulate streamflow and water quality parameters respectively. Comparisons of simulated and observed values revealed that the hydrology and water quality modules in the WEAP tool can effectively reproduce stream flows and water quality variables. Thus, the WEAP model can provide a virtually integrated simulation environment and scenario management to represent and examine the detailed impact of alternative water quality management scenarios. Simulated DO and BOD along the Bagmati River for 2020 and 2030 were compared with 2014 values to assess the current situation and future prospects of Bagmati River pollution in the Kathmandu Valley.

The simulation results show that the current practice of discharging untreated sewage into the river system is causing widespread pollution that becomes hazardous during drier periods. The proposed WWTP were found to be largely inadequate in reducing the extent and duration of river water pollution. The results also indicate that water quality is largely unsuitable for any practical use in between of Gaurighat to the Chovar area. An alternative approach to resolving the water pollution problem in Kathmandu Valley is to reduce wastewater and expand wastewater collection and treatment systems, which impact significantly on reducing the river water pollution of the valley. Result and recommendation of this study will be really useful for the professional and policy makers involved in water resource management if implemented properly. In summary, the severe deterioration of water quality in the Bagmati River requires action. It is essential to integrate river water pollution management in order to protect water quality and maintain ecologically and economically healthy urban development of the Kathmandu Valley.

\subsection{Recommendation}

Although this research has not incorporated a high level of details, its preliminary results can help local policy makers and water planners to achieve better management of the pollution by 2030. Sustainable wastewater management should incorporate various combinations of water quality parameters, wastewater generation, and treatment systems. BOD value of $15 \mathrm{mg} / \mathrm{l}$ was considered a critical value (acceptable water quality) in this study. Many previous studies for other cities considered much a smaller BOD value for defining acceptable water quality limit. Therefore, it is important to examine further alternative critical values for different river water quality parameters when assessing the current situation and future prospects of the river pollution. The sewerage system of Kathmandu valley is of the combined type, designed to collect rainwater runoff, domestic sewage, and industrial wastewater in the same pipe. Land use, land cover and climate change affect the quantity and quality characteristics of the rainwater runoff. Therefore, land use and land cover changes should be questions included in the future assessment of Bagmati river water pollution. Uncertainty associated with the climate change impacts can be reduced by considering outputs of multiple GCM (Global Climate Model) and RCP (Representative Concentration Path). Similar to other rivers in the cities in developing nations, Bagmati River is burdened with the dumping of solid wastes. Water quality degradation from solid waste disposal should also be considered while planning for river pollution management.

\section{Acknowledgements}

This research was supported by the Water and Urban Initiative (WUI) Project of the United Nations University Institute for the Advanced Study of Sustainability (UNU-IAS). The authors would like to thank the WUI members and several others for their comments and suggestions related to this research. The authors also thank Environmental Services Nepal (P) Ltd for assisting in data collection and organizing local stakeholders meeting to collect their valuable comments.

\section{References}

ADB, 2013. Kathmandu Valley Wastewater Management Project, Draft Initial Examination Report, Asian Development Bank (ADB), Project Number: 43524014, Manila, Philippines.

Amato, C.C., McKinney, D.C., Ingol-Blanco, E., Teasley, R.L., 2006. WEAP Hydrology Model Applied: The Rio Conchos Basin, Center for Research in Water Resources, The University of Texas. Austin, USA, available online at: http://www.ce.utexas.edu/centers/crwr/reports/online.html (Accessed on August 11, 2015).

Assaf, H., Saadeh, M., 2008. Assessing water quality management options in the Upper Litani Basin, Lebanon, using an integrated GIS-based decision support system. Environ. Modell. Software 23, 1327-1337.

Bhutiani, R., Khanna, D.R., 2007. Ecological study of river Suswa: modeling DO and BOD. Environ. Monit. Assess. 125, 183-195.

Bowie, G.L., Mills, W.B., Porcella, D.B., Campbell, C.L., Pagenkopf, J.R., Rupp, G.L., Johnson, K.M., Chan, P.W.H. and Gherini, S.A., 1985. In: Rates, Constants and Kinetics Formulations in Surface Water Quality Modeling, 2nd ed. US EPA, Athens, Georgia EPA 600/3-85/040.

Cox, B.A., 2003. A review of currently available in-stream water-quality models and their applicability for simulating dissolved oxygen in lowland rivers. Sci. Total Environ. 314-316, 335-377.

Deksissa, T., Meirlaen, J., Ashton, P.J., Vanrolleghem, P.A., 2004. Simplifying dynamic river water quality modelling: a case study of inorganic dynamics in the Crocodile River, South Africa. Water Air Soil Pollut. 155, 303-320.

GoN/NTNC, 2009. Bagmati Action Plan (2009-2014), Kathmandu, Nepal.

Gower, A.M., 1980. Water Quality in Catchment Ecosystems. JohnWiley \& Sons, NewYork.

ICIMOD, 2007. Kathmandu valley environment outlook. international center for integrated mountain development (ICIMOD), Kathmandu, Nepal.

Ingol-Blanco, E., McKinney, D., 2013. Development of a hydrological model for the rio Conchos basin. J. Hydrol. Eng. 18 (3), $340-351$.

Ismail, A.H., Abed, G.A., 2013. BOD and DO modeling for Tigris River at Baghdad city portion using QUAL2K model. J. Kerbala Univ. 11 (3), 257-273.

Kannel, P.R., Lee, S., Lee, Y.S., Kanel, S.R., Pelletier, G.J., 2007. Application of automated QUAL2Kw for water quality modeling and management in the Bagmati River, Nepal. Ecol. Modell. 202, 503-517. 
Lai, Y.C., Tu, Y.T., Yang, C.P., Surampalli, R.Y., Kao, C.M., 2013. Development of a water quality modeling system for river pollution index and suspended solid loading evaluation. J. Hydrol. 478, 89-101.

McIntyre, N.R., Wheater, H.S., 2004. A tool for risk-based management of surface water quality. Environ. Modell. Software 19, 1131-1140.

Moriasi, D.N., Arnold, J.G., Liew, M.W., Binger, R.L., Harmel, R.D., Veith, T.L., 2007. Model evaluation guidelines for systematic quantification of accuracy in watershed simulations. T. ASABE 50 (3), 885-900.

Nash, J.E., Sutcliffe, J.V., 1970. River flow forecasting through conceptual models, part I: a discussion of principles. J. Hydrol. 10, $282-290$.

Purandara, B.K., Varadarajan, N., Venkatesh, B., Choubey, V.K., 2011. Surface water quality evaluation and modeling of Ghataprabha River, Karnataka, India. Environ. Monit. Assess. 184 (3), 1371-1378.

Radwan, M., Willems, P., El-Sadek, A., Berlamont, J., 2003. Modelling of dissolved oxygen and biochemical oxygen demand in river water using a detailed and a simplified model. Int. J. River Basin Manage. 1 (2), 97-103.

Regmi, S., 2013. Wastewater treatment in Kathmandu: management, treatment and alternative Bachelor's Thesis. Mikkeli University of Applied Sciences, Finland.

Regmi, R.K., Mishra, B.K., Luo, P., Toyozumi, A., Fukushi, K. and Takemoto, K., 2014. A preliminary trend analysis of DO and BOD records in Kathmandu, Nepal: Towards improving urban water environment in Developing Asian Countries, Proceedings of 11th International Symposium on Southeast Asian Water Environment, Vol. 11, pp. 371-376.

Sieber, J., Purkey, D., 2011. Water Evaluation And Planning, WEAP, User Guide. Stockholm Environment Institute, USA.

Shrestha, N., Lamsal, A., Regmi, R.K. and Mishra, B.K., 2015. Current Status of Water Environment in Kathmandu Valley, Nepal, Water and Urban Initiative Working Paper Series, United Nations University - Institute for the Advanced Study of Sustainability, No. 03, pp. 1-5.

Shukla, A.K., Timilsina, U.R., Jha, B.C., 2012. Wastewater Production, Treatment and Use in Nepal available online at: http://www.ais.unwater.org/ ais/pluginfile.php/232/mod_page/content/120/Nepal_CountryPaper.pdf. Accessed on June 15, 2015.

Slaughter, A.R., Mantel, S.K. and Hughes, D.A., 2014. Investigating possible climate change and development effects on water quality within an arid catchment in South Africa: a comparison of two models, In: Ames, D.P., Quinn, N.W.T., Rizzoli, A.E. (Eds.), Proceedings of the 7th International Congress on Environmental Modelling and Software, June 15-19, San Diego, California, USA. ISBN: 978-88-9035-744-2.

UNEP, 2001. Nepal: State of the Environment, United Nations Environment Program (UNEP).

Yates, D., Sieber, J., Purkey, D., Huber-Lee, A., 2005. WEAP21 - A demand-, priority-, and preference-driven water planning model part 1: model characteristics. Water Int. 30 (4), 487-500. 